\title{
National eponyms in medicine
}

\author{
Barbara Nieradko-Iwanicka \\ Chair and Department of Hygiene, Medical University of Lublin, Poland
}

\section{Dear Editor,}

Giving a name to a street, school, lecture hall or hospital creates an individual space for these places and is a tribute to the person whose name is taken. In medicine, there has been a long tradition of commemorating the names of discoverers of disease phenomena, diagnostic tests and similar activities. On one hand, it facilitated communication between clinicians and researchers, but, as will be presented below, it does not always unify the name of the disease or facilitate contact between specialists. It also carries the risk of assessing history and the need to erase a person from its glorious chapters.

By definition, an eponym is a person, place or thing after whom or after which something is named. Especially in the past, eponyms were commonly used in medical vocabulary. "The French disease" or "the Italian disease" both meant syphilis, while "Spanish disease" was the name given to the great flu pandemic in 1918-1919. The "Guinea worm" is another name of Dracunculus medinensis (a parasite). The places of the first description of certain infectious diseases are remembered in such disease names as "German measles", "Marburg virus disease", "St Louis encephalitis" and "Rocky Mountain spotted fever". Among Polish references there are "plica polonica" and "Poland syndrome", the former meaning hair felting associated with lice eggs on hair, chemotherapy, azathioprine-induced pancytopenia, seborrheic dermatitis, schizophrenia, rupioid psoriasis, trichoma, pediculosis capitis and scabies [1]. Although in Polish medical literature it was first described in 1793 [2], in western Europe it became known after the publication of Joseph Kerchoff in 1814 [3]. His service as a military surgeon in the Napoleonic French Army inspired him to write about frequent occurrence of the entity in Poland, in Tartary, among Cossacks of Russia, in Hungary and in a few instances in Switzerland and France [3]. Now the disease is more often called "plica neuropathica".

The latter - an anomaly called "Poland syndrome" was first described by Alfred Poland. He was a medical student at Guy's Hospital in 1840-1841. Poland recognized absence of the major pectoral muscle in a 27 -yearold ex-convict and published the case report in 1841 [4]. Other authors also described a few cases of congenital absence of pectoral major and minor muscles on one side of the body accompanied by chest and upper extremity deformities on the same side [5].

In the $21^{\text {st }}$ century eponyms are rarely used because of the global importance of evidence-based medicine and multi-center cohort studies and clinical trials. Some eponyms were withdrawn because of controversial facts from scientists' lives. Among many others, such bad examples include Schilling's formula, Reiter's syndrome and Wegener's granulomatosis.

Although in connection with the above negative experiences and a tendency to avoid the use of eponyms, the enormous progress of knowledge creates many new names for diseases or pathophysiological phenomena, we are constantly looking for reasons to be proud of those who have gone down in the history of medicine in the best way. Knowledge about still used eponyms of Polish origin such as Browicz-Kupfer cells [6], Lesniowski-Crohn's disease [7], the surgery by the Rydygier method [8] or Biernacki's reaction (known worldwide as erythrocyte sedimentation rate - ESR) [9], makes us proud. The Babiński sign remains today a most important symptom of damage of the pyramidal system [10]. There have been many Polish Jewish doctors, e.g. Flatau and Goldflam, whose names we still use in medical terminology $[11,12]$. It is also known that within former Poland's borders there were especially outstanding scientists, such as Rudolf Weigl, who developed the first effective and practical vaccine against typhus, saving many Polish people in Lviv who fed lice during the Nazi occupation [13]. Our great Nobel laureate Maria Skłodowska-Curie, who had worked in Paris, discovered the basics of radioactivity and immortalized the name of our country by giving the name for the radioactive element Polonium (Po).

\section{Address of correspondence:}

Barbara Nieradko-Iwanicka, Chair and Department of Hygiene, Medical University of Lublin, 11 Radziwiłłowska St., 20-080 Lublin, Poland, e-mail: bnieradkoiwanicka@wp.pl

Submitted: 11.01.2020; Accepted: 31.01.2020 
This letter is not intended to be fully scientifically elaborated, but wants to draw attention to this issue and encourage discussion. Perhaps it is necessary to discuss the appropriateness of using eponyms and the desirability of commemorating those who are historically important and do not bring ethical controversy.

The author declares no conflict of interest.

\section{References}

1. Ohry A, Ohana N. On Plica Polonica and the forgotten Joseph Romain Louis Kerckhoffs (1789-1867). Prog Health Sci 2018; 8: 208-212, DOI: 10.5604/01.3001.0012.1331.

2. Perzyna L. Lekarz dla włościan. Kalisz 1793.

3. Kerchove-Varent L. Observations medicales: faites pendant les Campagne de Russiaeen 1812 et d'Allemagne 1813. L. Th. Nypels, aine, Maestricht 1814.

4. Poland A. Deficiency of the pectoral muscles. Guys Hosp Rep 1841; 6: 191-193.

5. Konuk S. Poland syndrome case study. Arch Clin Med Case Rep 2019; 3: 135-139, DOI: 10.26502/acmcr.96550071.

6. Burdan F, Szumilo J, Korobowicz A, et al. Biochemical and immunohistochemical study on physiological activity and distribution of hepatic cathepsin D. Acta Physiol Hung 2003; 90: 47-56, DOI: 10.1556/APhysiol.90.2003.1.6.
7. Geraci A, Tomasello G, Sabetta SP. Orthopaedic experience on inflammatory bowel disease (Lesniowski-Crohn's disease and ulcerative colitis). Ortop Traumatol Rehabil 2010; 12: 430-434.

8. Pach R, Orzel-Nowak A, Scully T. Ludwik Rydygier - contributor to modern surgery. Gastric Cancer 2008; 11: 187-191, DOI: 10.1007/s10120-008-0482-7.

9. Grzybowski A, Sak J. Edmund Biernacki (1866-1911): Discoverer of the erythrocyte sedimentation rate. On the $100^{\text {th }}$ anniversary of his death. Clin Dermatol 2011; 29: 697-703, DOI: 10.1016/j.clindermatol.2011.08.033.

10. Ambesh P, Paliwal VK, Shetty V, Kamholz S. The Babinski Sign: A comprehensive review. J Neurol Sci 2017; 372: 477-481, DOI: 10.1016/j.jns.2016.10.041.

11. Kaya Y, Akkoyunlu G, Sarikcioglu L. Edward Flatau (1868-1932) and his eponym. Childs Nerv Syst 2015; 31: 1995-1997, DOI: 10.1007/s00381-014-2569-2.

12. Gutowski JM. Edward Flatau (1868-1932), Samual Goldflam (1852-1932) and Józef Babinski (1857-1932): Polish pioneers in neurology. J Med Biogr 2016; 24: 101-109, DOI: 10.1177/0967772014525099.

13. Szybalski W. The genius of Rudolf Stefan Weigl (1883-1957), a Lvovian microbe hunter and breeder. In Memoriam. In: International Weigl Conference (Microorganisms in Pathogenesis and their Drug Resistance - Programme and Abstracts; R. Stoika et al. eds.). Sept 11-14, 2003. Lviv, Ukraine. 